\title{
HUBUNGAN ANTARA PENGETAHUAN SISWA TENTANG KESEHATAN REPRODUKSI DAN LOCUS OF CONTROL DENGAN PERILAKU HIDUP SEHAT
}

\author{
Ahmad Khoiri $^{1}$ \\ ${ }^{1}$ Pascasarjana Universitas Negeri Jakarta Gedung Bung Hatta Jl. Rawamangun Muka, \\ Jakarta Timur, Indonesia 13220, email:ahmadkhoiri@gmail.com
}

\begin{abstract}
The purpose of this study was to gain an overview of the relationship between students' knowledge of reproductive health and locus of control (LOC) with a Healthy Lifestyle. Students are expected to behave menyadaari the importance of healthy living. This study uses correlational method, the sample is 120 students drawn randomly. Data were collected using the instrument in the form of grains form of statements and questions. Analysis and interpretation of data showing (1) there is a positive relationship between students 'knowledge about reproductive health with a healthy behavior, (2) there is a positive relationship between locus of control students with healthy behavior, (3) there is a positive relationship between students' knowledge about health reproduction and locus of control together with healthy behavior. The findings of this study concludes with an increase students' knowledge about reproductive health, locus of control along healthy behaviors can improve the students the importance of maintaining health.
\end{abstract}

Keyword: students' knowledge about reproductive health, locus of control, and healthy behavior.

\section{PENDAHULUAN}

Permasalahan kesehatan remaja

di kota-kota besar termasuk kota Palembang sangat memprihatinkan, khusunya kehidupan seks bebas di kalangan remaja yang saat ini sudah menyebar di kota Palembang, bahkan ke perdesaan. Hal tersebut, dipicu oleh kurangnya pengetahuan akan kesehatan reproduksi. (A Rivai)

Robert S. Lawrencedkk (2001) juga mengatakan bahwa pada tahun 2003, 47 persen siswa SMA pernah 
melakukan hubungan seksual, dan 37 persen siswa yang aktif secara seksual tidak menggunakan kondom saat melakukan hubungan seksual terakhir mereka (Grunbaum et al., 2004).

Perilaku seksual tersebut sangat berisiko terhadap tingginya tingkat infeksi menular seksual. Penyakit infeksi menular seksual yang paling sering dilaporkan pada remaja dan terus meningkat populasinya, di antaranya: Chlamydia, gonorrhea, sifilis yang merupakan penyebab bakteri yang paling umum dari PMS.

Banyak perilaku tidak sehat dimulai pada masa remaja memperpanjang sampai dewasa dan menghasilkan morbiditas dan mortalitas yang signifikan dalam jangka pendek dan jangka panjang (Kolbe, Kann, dan Collins, 1993).

Bagian ini yang paling menonjol dari perilaku tersebut dan beberapa konsekuensi yang berhubungan dengan kesehatan mereka.

Pada tahun 2011 Komnas Perlindungan Anak (Komnas PA) pernah melakukan survei terhadap 14.726 sampel remaja di 12 kota besar di Indonesia, antara lain Jakarta, Bandung, Makassar, Medan, Lampung, Palembang, Kepulauan Riau. Hasilnya mengerikan. Hampir 83 persen mengaku pernah menonton video porno, sekitar 93,7 persen pernah melakukan hubungan seks, dan 21,2 persen mengaku pernah melakukan aborsi. Survei KPAI juga menyebutkan, 97 persen perilaku seks remaja diilhami pornografi di internet.

Perilaku seks bebas di kalangan remaja ini menghadirkan resiko kehamilan diluar nikah, gangguan kesehatan reproduksi hingga tertular HIV/AIDS. Kehamilan di usia muda dapat menyebabkan resiko kematian maternal karena ketidaksiapan organ reproduksi. Di samping itu, keluarga yang terbina karena kasus hamil di luar nikah sangat beresiko tidak siap mental dalam membina perkawinan yang harmonis dan menjadi orang tua yang bertanggung jawab.

Bila kondisi tersebut tidak segera diatasi, maka mimpi untuk memiliki generasi emas yang mampu mewujudkan cita-cita masa depan 
bangsa akan sulit diwujudkan. Oleh sebab itu, darurat kependudukan usia remaja saat ini mendesak ditanggulangi dengan segenap cara dan pendidikan yang tepat. Tentu semua pihak harus berperan serta, baik pemerintah, swasta maupun masyarakat. Jika tidak, akan semakin banyak generasi muda yang menyambut kelamnya masa depan di usia muda karena satu persatu terjerat dalam pergaulan bebas yang mengakibatkan penggunaan narkoba, kecanduan pornografi, seks bebas, maupun terpaksa menikah dini. Hal tersebut terjadi karena faktor lingkungan yang buruk dan kurangnya pengawasan keluarga terhadap anak dalam kehidupan sehari-hari.

Sekolah memiliki peran besar dalam kesejahteraan dan kesehatan anak-anak maupun generasi muda. Mempromosikan kesehatan siswa sama halnya dengan membantu pencapaian pendidikan, peningkatan pendidikan, dan membantu meningkatkan tingkat kesehatan. Selain itu, siswa sebagai remaja memiliki kebutuhan yang berbeda dari orang dewasa, sehingga program kesehatan seksual dan keluarga berencana yang ditujukan kepada kaum muda harus dirancang secara khusus untuk memenuhi kebutuhan dan bukan diadaptasi dari program yang sudah ada yang ditujukan kepada orang dewasa. Untuk itu, sangat penting pada usia remaja perlu pengetahuan remaja tentang kesehatan reproduksi, khususnya pada siswa agar dapat terhindar dari kehamilan yang tidak diinginkan, terlindung dari Infeksi Menular Seksual (IMS) dan dapat tumbuh menjadi orang dewasa yang berperilaku hidup sehat.

Kesehatan fisik dan mental merupakan faktor penting untuk menunjang semangat siswa dalam proses belajarnya. Hal ini menjadi landasan kuat peneliti untuk melakukan penelitian tentang perilaku hidup sehat siswa. Baik perilaku internal siswa yang percaya bahwa kemampuan, usaha, atau tindakan mereka sendiri menentukan apa yang terjadi pada mereka. Maupun perilaku eksternal siswa yang percaya bahwa nasib, keberuntungan, atau kekuatan luar yang bertanggung jawab atas apa yang terjadi pada mereka. Maka 
peneliti tertarik untuk melakukan penelitian di kota Palembang untuk menggambarkan adanya hubungan antara pengetahuan siswa tentang kesehatan reproduksi dan locus of control dengan perilaku hidup sehat.

\section{Perilaku Hidup Sehat}

Dalam Robert

(2000:49-51), perilaku menurut Skinner adalah penguatan (reinforcemen). Skinner menggunakan istilah "operan" untuk respon yang menghasilkan konsekuensi tertentu. Skinner mengemukakan bahwa perilaku merupakan respon atau reaksi seseorang terhadap stimulus (rangsangan dari luar). Skinner juga berpendapat bahwa konsep perilaku digunakan untuk meningkatkan kerjasama dan penguatan memainkan peran penting dalam mendidik anak.

Dalam Duane P. Schultz and Sydney Ellen Schultz (2009:135), Freud berpendapat bahwa perilaku manusia ditentukan oleh masa lalu yaitu, dengan naluri dan dengan pengalaman masa kecil kita. Freud percaya bahwa semua perilaku adalah suatu tindakan, serta pikiran dan perasaan yang tidak terjadi secara tidak sengaja atau secara kebetulan. Sedangkan dalam John w. Berry (2002:53), perilaku menurut kerangka konsep Marshal adalah budaya sampai batas tertentu, hal ini karena spesies manusia pada dasarnya satu sosial. Dalam Duane P. Schultz and Sydney Ellen Schultz (2009:416), Bandura berpendapat bahwa perilaku dikendalikan atau ditentukan oleh individu, melalui proses kognitif, dan lingkungannya, melalui kegiatan stimulus sosial eksternal.

Dari uraian tersebut, maka perilaku yang dimaksud dalam penelitian ini adalah aktivitas atau kegiatan seseorang yang dapat diamati. Perilaku merupakan fungsi dari karakteristik individu dan lingkungan. Perilaku adalah respon atau reaksi seseorang terhadap stimulus (rangsangan dari luar). Objek perilaku dalam penelitian ini adalah yang berhubungan dengan hidup sehat.

Menurut Didier Jourdan (2011:7), sehat atau kesehatan dapat diartikan sebagai kondisi yang normal dari kehidupan manusia. Kesehatan 
adalah sumber daya yang perlu dijaga dan dilindungi. Untuk mencapai ini, semua aspek kesehatan harus diperhatikan, sebagaimana faktor yang menentukan, biologis, psikologis, sosial, ekonomi, budaya dan lingkungan. Dari penjelasan tentang kesehatan tersebut tentu usaha yang harus dilakukan dalam menjaga kesehatan fisik, mental dan sosial agar terhindar dari bahaya penyakit tentu harus ditingkatkan dengan dorongan diri kita terhadap perilaku-perilaku yang berkaitan dengan upaya atau kegiatan seseorang untuk mempertahankan dan meningkatkan kesehatannya.

Dari uraian tersebut, maka perilaku hidup sehat adalah aktivitas seseorang terhadap stimulus yang memunculkan suatu tindakan yang berkaitan dengan upaya untuk mempertahankan dan meningkatkan kesehatannya dalam kehidupan seharihari

Pengetahuan Siswa tentang Kesehatan Reproduksi
Menurut Thomas L. Good, dan

Jere E. Brophy (1990:130-131), pengetahuan merupakan hasil kegiatan keilmuan atau pikiran yang mengkombinasikan sensasi-sensasi pokok. Pengetahuan adalah hasil proses yang rumit dimana objek luar merangsang panca indra atau lebih yang menyebabkan perubahan dalamorgan badan. Manusia mencari pengetahuan dengan harapan bahwa pengetahuan tadi dapat berguna baginya untuk membantu memecahkan masalah kehidupan yang dihadapinya.

Sesuai yang dijelaskan oleh Benjamin S. Bloom (1979:201-204), pengetahuan diartikan sebagai ingatan khusus dan ingatan umum mengenai berbagai metode dan proses atau ingatan kembali tentang pola, struktur atau keadaan. Aspek pengetahuan diklarifikasikan dalam tiga kelompok dan diciri menjadi Sembilan aspek, yaitu (1) pengetahuan mengenai halhal yang bersifat khusus meliputi: istilah dan fakta, (2) pengetahuan tentang cara untuk mengenai maalahmasalah khusus meliputi: kebiasaan, kecendrungan, klasifikasi, kategori, metode dan (3) pengetahuan tentang 
kaidah yang bersifat universal meliputi: prinsip, teori, dan struktur.

Menurut Robert F. Rich(1981:4), Klasifikasi pengetahuan terbagi menjadi lima bagian besar yaitu:

pengetahuan praktis,digunakan dalam bidang pekerjaan yang berhubungan dengan pengambilan keputusan,

pengetahuan intelektual, digunakan untk menjawab keingintahuan dalam bidang-bidang intelektual misalnya bidang hokum, ekonomi, budaya dan lain sebagainya, (3) "Small talk", pengetahuan untuk menjawab keingintahuan yang sifatnya tidak intelektual, misalnya tentang rumor atau gosip, berita kriminal dan kecelakaan, cerita, permainan dan lainlain, (4) pengetahuan spiritual, menyangkut hubungan manusia dengan agama dan Tuhan, (5) pengetahuan tidak dikehendaki "unwanted knowledge" menyangkut sesuatu yang diluar perhatian seseorang, sesuatu yang diperoleh dengan tidak sengaja.

Davenport, Thomas H. and Lawrence Prusak berpendapat bahwa pengetahuan adalah pengalaman, nilai- nilai, informasi kontekstual, dan wawasan ahli yang memberikan kerangka untuk mengevaluasi dan menggabungkan pengalaman baru dan informasi

Menurut Roderick M. Chisholm(1989:90), Seseorang akan mempunyai pengetahuan yang mendalam jika mengetahui bahwa suatu kejadian menjadi bukti kebenarannya pada pengetahuanyang sudah diketahuinya. Menurut Richards J. Heuer, Jr (1999:22), pengetahuan berfungsi sesuai dengan karakteristik baru dalam perubahan lingkungan dan konteks. Hal ini juga menunjukkan bahwa bagaimana pengetahuan terhubung dalam memori sangat penting dalam menentukan informasi apa yang diambil dalam menanggapi stimulus apapun dan bagaimana informasi yang digunakan dalam penalaran. Pengetahuan akan selalu berkembang seiring dengan berbagai penelitian, perkembangan bukti untuk pembenaran pengetahuan tersebut dan kritik-kritik baru untuk memecahkan masalah.

Dari uraian tersebut maka dapat dijelaskan bahwa pengetahuan 
adalah segala sesuatu yang diketahui dan merupakan khasanah mental yang secara langsung maupun tak langsung turut memperkaya kehidupan manusia. Pengetahuan merupakan segala apa yang kita ketahui tentang alam lingkungan kita. Pengetahuan diartikan sebagai ingatan umum menguasai berbagai metode dan proses.Sasaran penelitian ini adalah pengetahuan siswa tentang kesehatan reproduksi. Oleh karena itu, perlu pembahasan tentang definisi kesehatan reproduksi.

Menurut

Didier

Jourdan(2011:7), kesehatan adalah sumber daya yang perlu dijaga dan dilindungi. Untuk mencapai ini, semua aspek kesehatan harus diperhatikan, sebagaimana seharusnya semua faktor yang menentukan itu, yang dapat biologis, psikologis, sosial, ekonomi, budaya dan lingkungan.Menurut $\mathrm{P}$. Nicolopoulou-Stamati (2007:2), reproduksi adalah subjek yang luas, dengan mekanisme dan sistem mulai dari molekul dengan sistem seluruh tubuh.Semua makhluk hidup memiliki nasib biologis yang umum, untuk memperbanyak atau menghadapi kepunahan. Dalam hal itu, mereka semua tergantung pada lingkungan mereka, untuk ketersediaan kondisi yang tepat untuk kelangsungan hidup individu sangat penting.

Dalam Farzaneh Roudi, Fahimi and Lori Ashford (2000:4), Kesehatan reproduksi dan kesehatan seksual pertama kali didefinisikan dalam Program Aksi Konferensi International Kependudukan dan Pembangunan Perserikatan Bangsa-Bangsa (PBB) pada tahun 1994 yang mengatakan bahwa kesehatan reproduksi adalah keadaan sejahtera fisik, mental dan sosial kesejahteraan dan bukan hanya tidak adanya penyakit atau kelemahan, dalam segala hal yang berkaitan dengan sistem reproduksi dan fungsi dan proses. Oleh karena itu, kesehatan reproduksi menyiratkan bahwa orang dapat memiliki kehidupan seks yang memuaskan dan aman dan bahwa mereka memiliki kemampuan untuk bereproduksi dan kebebasan untuk memutuskan apakah, kapan dan seberapa sering untuk melakukannya.

Menurut WHO (2006:4), Kesehatan reproduksi mempengaruhi kehidupan perempuan dan laki-laki dari konsepsi kelahiran, sampai remaja 
untuk usia tua, dan termasuk pencapaian dan pemeliharaan kesehatan yang baik serta pencegahan dan pengobatan gangguan kesehatan. Sedangkan dalam Arlette Campbell White,dkk (2006:13), Konferensi Internasional tentang Kependudukan dan Pembangunan (ICPD) yang diselenggarakan di Kairo tahun itu mengubah fokus yang sempit ini dengan mendefinisikan kembali kesehatan reproduksi sebagai keadaan fisik lengkap, mental dan kesejahteraan sosial dan tidak hanya adanya penyakit atau kelemahan, dalam segala hal yang berhubungan dengan sistem reproduksi dan fungsi serta prosesnya. Faktor risiko utama untuk kesehatan reproduksi yang buruk adalah seks yang tidak aman, subjek utama perhatian dalam kesehatan reproduksi hari ini. Seks yang tidak aman memiliki konsekuensi yang merugikan, termasuk HIV/AIDS, IMS, kehamilan yang tidak diinginkan, aborsi yang tidak aman, dan kekerasan seksual.

Mengatasi HIV/AIDS berarti menangani resiko dan kerentanan yang berkaitan dengan perilaku seksual.
Akibatnya, kesehatan reproduksi masyarakat telah mempengaruhi perubahan perilaku dan dukungan yang ditujukan untuk seks yang lebih aman, kesehatan remaja, keterlibatan laki-laki, kesadaran masyarakat, kebutuhan keluarga berencana, perempuan HIV-positif, dan pencegahan penularan penyakit dari ibu ke anak, serta konseling suka rela rahasia dan pengujian, deteksi, dan manajemen IMS. Sedangkan menurut Tracey J. Woodruff (2010:2), Kesehatan reproduksi merupakan kemampuan untuk hamil, untuk membawa kehamilan, kualitas kehamilan dan hasil, efek pubertas dan dewasa serta gangguan kesehatan reproduksi.

Dengan demikian pengetahuan tentang kesehatan reproduksi adalah segala sesuatu yang diketahui oleh seseorang dalam informasi berdasarkan aspek-aspek pengetahuan yang meliputi terminology atau istilah, fakta, kebiasaan, kecendrungan, klasifikasi dan kategori, kriteria, metodologi, prinsip dan generalisasi serta teori dan struktur yang berkenaan dengan kesehatan reproduksi baik 
kesehatan organ reproduksi, keadaan sosial dan Penyakit Menular Seksual (PMS).

\section{Locus Of Control (LOC)}

Menurut Robert B. Ewen (2014:353), locus of control adalah sifat yang didasarkan pada kognisi. Beberapa orang percaya bahwa mendapatkan penghargaan dan menghindari hukuman terutama dalam kendali mereka dan tergantung pada mereka perilaku sendiri (internal locus of control). Lainnya berharap pengalaman baik dan buruk mereka disebabkan sebagian besar secara kebetulan, nasib, dan tindakan orang lain (locus of control eksternal). Locus of control internal sejauh mana seseorang percaya bahwa mendapatkan penghargaan dan menghindari hukuman dalam kendali seseorang tergantung pada perilaku seseorang. Locus of control eksternal Sejauh mana seseorang percaya bahwa mendapatkan penghargaan dan menghindari hukuman karena kebetulan, nasib, dan tindakan orang lain. Menurut Rotter dalam Duane P. Schultz and Sydney Ellen Schultz
(2009:432-433), mendefinisikan locus of control sebagai berikut: Rotter sought explanations for behavior and personality outside and inside the organism, looking both to external reinforcements and internal cognitive processes. In the course of an extensive research program, he found that some people believe that their reinforcers depend on their own actions and that other people believe that their reinforcers are controlled by other people and by outside forces. He called this concept locus of control. Dalam penelitian yang dilakukan oleh Julian Rotter, ia menemukan bahwa beberapa orang percaya bahwa penguatan mereka bergantung pada tindakan mereka sendiri dan sebagian lainnya percaya bahwa penguatan mereka dikendalikan oleh orang lain dan dengan kekuatan-kekuatan luar. Konsep tersebut disebut locus of control.

Menurut Duane P. Schultz dan Sydney Ellen Schultz (2009:21),orangorang yang telah ditandai sebagai internal locus of control percaya bahwa penguatan yang mereka terima di bawah kendali perilaku mereka 
sendiri. Sedangkan mereka yang dengan locus of control eksternal berpikir bahwa orang lain, nasib, atau keberuntungan mengontrol imbalan yang mereka terima. Dengan kata lain, mereka yakin bahwa mereka tidak berdaya terhadap kekuatan-kekuatan luar. Sumber locus of control dapat memiliki cukup pengaruh pada perilaku kita. Eksternal locus of control, orang yang percaya bahwa perilaku mereka dan kemampuan membuat perbedaan dalam penguatan yang mereka terima, mungkin melihat nilai yang kecil dalam mengerahkan upaya untuk memperbaiki situasi mereka. Internal locus of control orang percaya bahwa mereka memiliki pegangan di situasi mereka dan berperilaku sesuai. Mereka tampil di tingkat yang lebih tinggi, dari pada eksternal locus of control. Selain itu, factor internal yang upaya untuk mempengaruhi mereka, menempatkan nilai tinggi pada keterampilan mereka, dan lebih waspada terhadap isyarat lingkungan yang mereka gunakan untuk memandu perilaku. Mereka melaporkan lebih rendah kecemasan dan lebih tinggi harga diri, lebih bertanggung jawab atas tindakan mereka, dan menikmati kesehatan mental dan fisik yang lebih besar.

Menurut Richard M. Ryckman (2008:571), kontrol eksternal maupun internal itu ditentukan sendiri (internal control) atau ditentukan oleh faktor luar (eksternal control). Ada kecenderungan percaya bahwa penguatan tunduk pada kendali mereka sendiri dan terjadi ketika mereka menampilkan keterampilan mereka. Orang berorientasi eksternal, sebaliknya, melihat sedikit atau tidak ada hubungan antara perilaku mereka dan berbagai penguatan; mereka melihat terjadinya penguatan yang ditentukan terutama oleh nasib, keberuntungan, atau orang lain yang kuat. Menurut Jess Feist dan Gregrory Feist (2008:546), locus of control merupakan harapan umum yang mengacu pada keyakinan masyarakat bahwa mereka dapat atau tidak dapat mengendalikan hidup mereka. Jhon R. Schermehorn (2011:34), mengatakan bahwa, locus of control adalah sejauh seseorang merasa mampu mengendalikan hidupnya sendiri dan berkaitan dengan orientasi internal- 
eksternal seseorang. Orang berbeda dalam berapa banyak kontrol mereka percaya bahwa mereka memiliki lebih dari situasi mereka dan atas apa yang terjadi pada mereka. Beberapa orang berpikir mereka memiliki relatif kecil terhadap lingkungan mereka dan sedikit kontrol atas hal-hal penting yang terjadi dalam hati mereka, yang lain percaya bahwa mereka dapat memiliki dampak besar pada dunia di sekitar mereka dan di jalan hidup mereka ambil. locus of control sifat menangkap perbedaan antara individu.

\section{Locus of control adalah sejauh} mana orang percaya bahwa perilaku mereka memiliki efek nyata pada apa yang terjadi pada mereka. beberapa orang, misalnya, percaya bahwa jika mereka bekerja keras mereka akan berhasil. mereka juga percaya bahwa orang yang gagal melakukannya karena mereka tidak memiliki kemampuan atau motivasi. Orangorang yang percaya bahwa individu berada dalam kendali kehidupan mereka dikatakan memiliki internal locus of control. Orang lain berpikir bahwa nasib, kesempatan, keberuntungan, atau perilaku orang lain menentukan apa yang terjadi pada mereka.

Locus of control didefinisikan sebagai keyakinan umum seseorang tentang jumlah kontrol dia memiliki lebih dari peristiwa kehidupan pribadi. individu dengan internal locus of control percaya bahwa karakteristik pribadi mereka (yaitu, motivasi dan kompetensi) terutama hasil pengaruhkehidupan. Orang-orang dengan dari locus of control eksternal lebih percaya bahwa peristiwa dalam kehidupan mereka terutama karena nasib, keberuntungan, atau kondisi di luar lingkungan. locus of control adalah keyakinan umum, sehingga orang-orang dengan nuansa eksternal akrab dalam situasi (seperti melakukan tugas biasa). Namun, locus of control yang mendasari mereka akan menjadi jelas dalam situasi baru di mana kontrol mereka atas peristiwa tidak pasti. Orang dengan locus control internal lebih memiliki evaluasi diri yang lebih positif. mereka juga cenderung tampil yang paling lebih baik dalam situasi kerja, lebih sukses dalam karier mereka, mendapatkan lebih banyak uang, dan lebih cocok 
untuk posisi kepemimpinan. internal juga lebih puas dengan pekerjaan mereka, mengatasi lebih baik dalam situasi stres, dan lebih termotivasi oleh sistem penghargaan berbasis kinerja. Salah satu pengamatannya adalah bahwa orang-orang muda telah signifikan bergeser membentuk internal untuk lebih dari locus of control eksternal lebih dari empat dekade sejak awal tahun 1960, (dalam McShane, 2013:73).

Dari beberapa uarian di atas peneliti menyimpulkan bahwa Locus of control adalah penilaian seseorang terhadap dirinya sendiri tentang sifat yang dimilikinya berkaitan dengan kesuksesan dan kegagalan pada dirinya, apakah disebabkan oleh faktor dirinya sendiri maka sifat seseorang tersebut termasuk locus of control (loc) internal, ataukah karena faktor lain yang ada di luar diri sendiri maka sifat seseorang tersebut termasuk locus of control (loc) eksternal.

\section{METODOLOGI PENELITIAN}

Penelitian ini menggunakan pendekatan kuantitatif dengan teknik korelasional. Populasi target dalam penelitian ini adalah siswa - siswi Sekolah Menengah Atas (SMA) di Kota Palembang. Dari pra survei yang dilakukan pada lokasi penelitian diketahui populasi target berjumlah sebesar 7.779 orang.

Pengambilan sampel dilakukan dengan cara mutistages random sampling (teknik pengambilan sampel secara random bertahap), dengan langkah-langkah sebagai berikut: (1) Ditentukan terlebih dahulu wilayah daerah sampel, dalam hal ini lokasi sekolah berada di wilayah Kota Palembang yang terpilih dengan cara pengambilan sample cluster random. (2) Melalui cluster sampling diambil tiga sekolah dari 24 yang ada di wilayah kota Palembang yaitu SMA Negeri 13 Palembang, SMA Negeri 19 Palembang dan SMA Negeri 22 Palembang, (3) Dari tiga sekolah yang terpilih, kemudian dipilih kembali secara cluster sampling masingmasing 2 kelas sehingga berjumlah enam kelas, (4) Dari enam kelas yang terpilih masing-masing kelas dipilih 20 (dua puluh) siswa mewakili siswa secara simple random sampling (sampel acak sederhana). siswa yang 
terpilih sebagai sampel adalah $6 \times 20=$ 120 (seratus dua puluh) siswa, sehingga responden dalam penelitian ini adalah siswa dari sekolah yang berada di wilayah kota Palembang yang jumlahnya sebanyak 120siswa.

\section{HASIL DAN PEMBAHASAN}

\section{Hipotesis pertama menyatakan terdapat hubungan antara Pengetahuan Siswa tentang Kesehatan Reproduksi dengan Perilaku Hidup Sehat}

Berdasarkan hasil penghitungan terlihat antara Pengetahuan Siswa tentang Kesehatan Reproduksi dengan Perilaku Hidup Sehat terdapat hubungan yang positif dan sangat signifikan. Koefisisen korelasi sebesar 2,102. Angka korelasi ini menunjukkan hubungan yang kuat antara Pengetahuan Siswa tentang Kesehatan Reproduksi dengan Perilaku Hidup Sehat. Dikatakan signifikan karena diperoleh $t_{\text {hitung }}$ lebih besar dari $\mathrm{t}_{\text {tabel }}$ pada $\alpha=0,05$ sehingga hipotesis nol $\left(\mathrm{H}_{0}\right)$ ditolak yaitu $\mathrm{t}_{\text {hitung }}>$ $t_{\text {tabel }} \quad(2,102>1,980) . \quad$ Adanya hubungan yang sangat signifikan, maka tinggi rendahnya Perilaku Hidup Sehat dapat diprediksi melalui keseuaian Pengetahuan Siswa tentang Kesehatan Reproduksi. Kontribusi yang diberikan Pengetahuan Siswa tentang Kesehatan Reproduksi terhadap Perilaku Hidup Sehat sebesar $3,6 \%$. Angka ini menunjukkan sumbangan yang sangat berarti, dimana Perilaku Hidup Sehat akan berubah sebesar 3,6\% karena adanya sumbangan Pengetahuan Siswa tentang Kesehatan Reproduksi.

Dari hasil pengujian secara parsial, menunjukkan bahwa terdapat hubungan yang sangat signifikan antara Pengetahuan Siswa tentang Kesehatan Reproduksi dengan Perilaku Hidup Sehat setelah Locus of Control (LOC) dilakukan pengontrolan. Keadaan ini dapat diartikan bahwa semakin tinggi Pengetahuan Siswa tentang Kesehatan Reproduksi selalu diikuti tingginya Perilaku Hidup Sehat sekalipun Locus of Control (LOC) dianggap konstan. Hal ini juga berlaku sebaliknya, semakin tidak sesuai Pengetahuan Siswa tentang Kesehatan Reproduksi selalu diikuti rendahnya Pengetahuan 
Siswa tentang Kesehatan Reproduksi.

Kenyataan ini mengisyaratkan bahwa

Pengetahuan Siswa tentang Kesehatan

Reproduksi memberikan sumbangan yang sangat berarti terhadap peningkatan Perilaku Hidup Sehat.

\section{Hipotesis Kedua Terdapat} Hubungan Positif antara Locus of Control dengan Periaku Hidup Sehat

$\begin{array}{lcr}\text { Hasil analisis } & \text { pengujian } \\ \text { hipotesis } & \text { menunjukkan } & \text { terdapat } \\ \text { hubungan } & \text { posistif dan } & \text { sangat } \\ \text { signifikan } & \text { antara Locus of } & \text { Control }\end{array}$
(LOC) dengan Perilaku Hidup Sehat. Koefisisen korelasi sebesar 2,442. Angka korelasi ini menunjukkan hubungan yang kuat antara Locus of Control (LOC) dengan Perilaku Hidup Sehat. Dikatakan signifikan karena diperoleh $t_{\text {hitung }}$ lebih besar dari tabel pada $\alpha=0,05$ sehingga hipotesis nol $\left(\mathrm{H}_{0}\right)$ ditolak yaitu $t_{\text {hitung }}>t_{\text {tabel }}$ $(2,442>1,980)$. Adanya hubungan yang sangat signifikan, maka tinggi rendahnya Perilaku Hidup Sehatsiswa dapat diprediksi melalui tinggi rendahnya Locus of Control (LOC).
Kontribusi yang diberikan variabel Locus of Control (LOC) terhadap Perilaku Hidup Sehat sebesar 4,80\%. Angka ini menunjukkan sumbangan yang sangat berarti, dimana Perilaku Hidup Sehatsiswa akan berubah sebesar 4,80\% karena adanya sumbangan Locus of Control (LOC).

Dari hasil pengujian secara parsial, menunjukkan bahwa terdapat hubungan yang sangat signifikan antara Locus of Control (LOC) dengan Perilaku Hidup Sehat setelah Pengetahuan siswa tentang kesehatan reproduksi dilakukan pengontrolan. Keadaan ini dapat diartikan bahwa semakin tinggi Locus of Control $(L O C)$ selalu diikuti tingginya Perilaku Hidup Sehat sekalipun Pengetahuan Siswa tentang Kesehatan Reproduksi dianggap konstan. Hal ini juga berlaku sebaliknya, semakin rendah Locus of Control (LOC) selalu diikuti rendahnya Perilaku Hidup Sehat. Kenyataan ini mengisyaratkan bahwa Locus of Control (LOC) memberikan sumbangan yang sangat berarti terhadap peningkatan Perilaku Hidup Sehat. 
3. Hipotesis ketiga terdapat hubungan positif antara Pengetahuan Siswa tentang Kesehatan Reproduksi dan Locus of Control(LOC) Secara Bersama-Sama dengan Perilaku Hidup Sehat

Hasil analisis pengujian hipotesis menunjukkan terdapat hubungan posistif dan sangat signifikan antara Pengetahuan Siswa tentang Kesehatan Reproduksi dan Locus of Control (LOC) secara bersama-sama dengan Perilaku Hidup Sehat. Koefisisen korelasi ganda sebesar 5,222. Angka korelasi ini menunjukkan hubungan yang kuat antara Pengetahuan Siswa tentang Kesehatan Reproduksi dan Locus of Control (LOC) secara bersama-sama dengan Perilaku Hidup Sehat. Dikatakan sangat signifikan karena diperoleh $\mathrm{F}_{\text {hitung }}$ lebih besar dari $\mathrm{F}_{\text {tabel }}$ pada $\alpha=0,05$ sehingga hipotesis nol $\left(\mathrm{H}_{0}\right)$ ditolak yaitu $\mathrm{F}_{\text {hitung }}>\mathrm{F}_{\text {tabel }}$ $(5,222>3,074)$. Adanya hubungan yang sangat signifikan, maka tinggi rendahnya Perilaku Hidup Sehat dapat diprediksi melalui sesuai tidaknya
Pengetahuan Siswa tentang Kesehatan Reproduksi dan tinggi rendahnya Locus of Control (LOC) secara bersma-sama. Kontribusi yang diberikan variabel Pengetahuan Siswa tentang Kesehatan Reproduksi dan Locus of Control (LOC) secara bersama-sama terhadap Perilaku Hidup Sehat sebesar 8,20\%. Angka ini menunjukkan sumbangan yang sangat berarti, dimana Perilaku Hidup Sehat akan berubah sebesar 8,20\% karena adanya sumbangan Pengetahuan Siswa tentang Kesehatan Reproduksi dan Locus of Control (LOC) secara bersama-sama.

\section{KESIMPULAN}

Penelitian ini memiliki kesimpulan sebagai berikut: (1) Terdapat hubungan positif antara pengetahuan siswa tentang kesehatan reproduksi dengan perilaku hidup sehat. Dalam arti semakin tinggi pengetahuan tentang kesehatan reproduksi yang dimiliki siswa, maka semakin positif perilaku mereka terhadap hidup sehat. (2) Terdapat hubungan positif antara locus of control siswa dengan perilaku hidup 
sehat. Dalam arti semakin tinggi locus

of control yang dimiliki siswa, maka semakin positif perilaku mereka terhadap hidup sehat. (3) Terdapat hubungan positif antara pengetahuan siswa tentang kesehatan reproduksi dan locus of control secara bersamasama dengan perilaku hidup sehat. Dalam arti semakin tinggi pengetahuan siswa tentang kesehatan reproduksi dan tingginya locus of control yang dimiliki siswa, maka semakin positif perilaku mereka terhadap hidup sehat.

\section{DAFTAR PUSTAKA}

A Rivai, "Seks Bebas Remaja Makin Mempreihatinkan", Palembang Pos, $12 \quad$ November 2012. http://palembangpos.com/index.php?option=co $\mathrm{m} \_$content $\&$ view $=$ article $\& i d=6$ 984:seks-bebas-remaja-makinmemprihatinkan\&catid $=70$ :plembangkito\&Itemid=76 (diakses pada 12 November 2014).

Berry John w., et al. 2002. CrossCultural Psychology : Research and Applications. USA: Cambridge University Press.

Bloom, Benjamin S (ed),. 1979. Taxonomy of Educational Objective. Lon-don: longman Ltd.
Chisholm, Roderick M. 1989. Theory Of Knowladge. New Jersey: Prentise Hall Inc.

Didier, Jourdan. 2011. Health education in schools The challenge of teacher training Saint-Denis- France : Inpes, coll. Santé en action.

Ewen, Robert B. 2014. An introduction To theories of Personality, New York: Psychology Press.

Fahimi, Farzaneh Roudi and Ashford, Lori.Sexual \&Reproductive Health in the Middle East and North Africa.Washington DC: Population Reference Bureau, 2000.

Farih, Manal, et al.,Protocol study: sexual and reproductive health knowledge, informationseeking behavi-ur and attitudes among Saudi women: a questionnaire survey of university students, http://www. Reproductivehealthjournal.com/content/11/1/34 Women's London : Queen Mary University of LondonHealth Research, 2014)., h.7.

Feist, Jess and Feist, Gregrory. 2008. Theories of Personality.USA: The McGraw.

George, Jennifer M. and Jones, Gareth R. 2005. Understanding And Managing Organizational Behavior. USA: Pearson Prentice Hall. 
Grotz, Marlene.,et al., "Health locus of control and health behaviour: Results from a nationally representative surve", Psychology, Health \& Medicine Vol. 16, No. 2, Germany: University of Freiburg, Taylor \& Francis, 2011

Good, Thomas L,. Brophy, Jere E. Educational Psychology. New York: Longman, 1990.

Heuer, Jr. Richards J. Psychology of Intelligence Analysis, US Government: Central Intelli-gence Agency, 1999.

Lawrence Robert S. et al., 2001. Adolescent Health Services: Missing Opportunities. Washington, DC :The National Academies Press.

Martino," Mewujudkan Generasi Berencana via Ranah Broadband"http://inspiringindo nesia.blogdetik.com/2013/08/2 8/mewujudkan-generasiberencana-via-ranah-broadband (diakses 24 Desember 2014)

Robert D. Nye.,Three Psychologies Perspectives from Freud, Skinner, and Rogers. USA: Wadsworth/Thomson Learnin., 2000 .

Rich, Robert F. The Knowladge Cycle.London: Sage Publications, 1981.
Ryckman, Richard M. Theories of Personality.USA : Thomson Wadsworth, 2008.

Schermehorn, Jhon R. Jr. et al., Organizational Behavior. USA: John Wiley \& Sons, Inc, 20011

Schultz, Duane P. and Schultz, Sydney Ellen. 2009. Theories of Personality-Ninth Edition.USA : Wadsworth, Cengage Learning.

Stamati P. Nicolopoulou, et al., Reproductive Health and the Environment. The Netherlands: Springer- Library of Congress. 2007.

Thomas H. Davenport and Lawrence Prusak, "Working Knowledge: How Organizations Manage What They Know" "http://www.kushima.org /is/wpcontent/uploads/2013/09/ Davenport know.pdf (diakses 23/12/2014).

White, Arlette

Campbell. Merrick,Thomas W. and Yazbeck, Abdo S. 2006. Reproductive Health; The Missing Millennium Development Goal. Washington, DC: The World Bank.

Woodruff, Tracey J., et al. 2010. Environmental Impacts on Reproductive Health and Fertility. USA: Cambridge University Press. 